\title{
Purification of blood coagulation factors II, VII, IX and $X$ from bovine citrated plasma
}

Citation for published version (APA):

Reekers, P., \& Hemker, H. C. (1972). Purification of blood coagulation factors II, VII, IX and X from bovine citrated plasma. Pathophysiology of Haemostasis and Thrombosis, 1(1), 2-22.

https://doi.org/10.1159/000213734

Document status and date:

Published: 01/01/1972

DOI:

10.1159/000213734

Document Version:

Publisher's PDF, also known as Version of record

\section{Please check the document version of this publication:}

- A submitted manuscript is the version of the article upon submission and before peer-review. There can be important differences between the submitted version and the official published version of record.

People interested in the research are advised to contact the author for the final version of the publication, or visit the DOI to the publisher's website.

- The final author version and the galley proof are versions of the publication after peer review.

- The final published version features the final layout of the paper including the volume, issue and page numbers.

Link to publication

\footnotetext{
General rights rights.

- You may freely distribute the URL identifying the publication in the public portal. please follow below link for the End User Agreement:

www.umlib.nl/taverne-license

Take down policy

If you believe that this document breaches copyright please contact us at:

repository@maastrichtuniversity.nl

providing details and we will investigate your claim.
}

Copyright and moral rights for the publications made accessible in the public portal are retained by the authors and/or other copyright owners and it is a condition of accessing publications that users recognise and abide by the legal requirements associated with these

- Users may download and print one copy of any publication from the public portal for the purpose of private study or research.

- You may not further distribute the material or use it for any profit-making activity or commercial gain

If the publication is distributed under the terms of Article $25 \mathrm{fa}$ of the Dutch Copyright Act, indicated by the "Taverne" license above, 


\title{
Purification of Blood Coagulation Factors II, VII, IX and X from Bovine Citrated Plasma ${ }^{1}$
}

\author{
P. ReEKers ${ }^{2}$ and H. C. Hemker \\ Department of Internal Medicine, Laboratories of Cardiobiochemistry and Blood \\ Coagulation Biochemistry, University Hospital Leiden, Leiden
}

\begin{abstract}
The bovine coagulation factors II, VII, IX and X were separated from other plasma proteins, and each factor was obtained in a largely pure state by various chromatographic procedures in the presence of diisopropylfluorophosphate (DFP). Factor X was separated from factors II, VII, and IX by DEAE Sephadex chromatography, followed by G-100 filtration and hydroxylapatite chromatography. Separation of factors II and IX from factor VII was achieved by chromatography on DEAE cellulose, followed by G-100 gel filtration and hydro-

Key Words Purification Prothrombin Factor VII Factor IX Factor X Bovine plasma xylapatite chromatography. Factors II and IX were separated by preparative polyacrylamide electrophoresis

After DEAE cellulose chromatography, factor VII was purified by gradient elution from hydroxylapatite.
\end{abstract}

\section{Introduction}

The problem of obtaining coagulation factors II, VII, IX and X from plasma in a pure state has been a particularly stubborn one, and this difficulty has retarded progress in coagulation biochemistry appreciably. Methods

${ }_{1}$ The investigations were supported by the Netherlands Foundation for Chemical Research (SON) and Fundamental Medical Research (FUNGO), with financial aid from the Netherlands Organization for Advancement of Pure Research (ZWO). The skillfull technical assistance of Mrs.J.Ten Veen In 'T Veld, Mrs. B.H.M. Kop-Klaassen and Miss F. LAKMAKER is gratefully acknowledged.

${ }^{2}$ The work presented in this publication is part of the $\mathrm{PhD}$ thesis of one of the authors (P.R.).

\footnotetext{
Received: November 21, 1972; accepted: December 8, 1972.
} 
giving partial separation and yielding one or two of these factors in a pure state from the same plasma sample have occasionally been published since 1964. In this article, procedures will be described by which each of the four factors can be obtained separately from the same batch of bovine plasma, the resulting products being free of any other coagulation factor activity and very pure with respect to contaminating proteins. The initial steps consist of aluminum hydroxide adsorption and ammonium sulfate precipitation, as described in the literature for human or rabbit citrated plasma $[6,7,12,32,41,44]$. The other methods applied include chromatography, gel filtration and preparative polyacrylamide electrophoresis, ${ }^{3}$ partly along the lines indicated by investigations on the purification of single coagulation factors $[5,8,9,13,14,16,17,25,27,29,34-36,40,43,45]$. Following a suggestion of JACKSON and HANAHAN [17], we added DFP, $10^{-4} \mathrm{M}$, to all preparations and buffer solutions after the ammonium sulfate precipitation step to prevent activation of the coagulation factors.

\section{Materials and Methods}

\section{Chemicals and Special Reagents}

Aluminum hydroxide moist gel batch No.0340600, kaolin light, and DFP were obtained from British Drug House. Trizma base 121, hemoglobin, egg albumin, cytochrome c and tetra-methylethylene diamine (Temed) were purchased from Sigma. DEAE cellulose (DE-32) was obtained from Whatman Biochemicals. DEAE Sephadex A-50, Sephadex G-100 and dextran blue 2000 were obtained from Pharmacia. Hydroxylapatite Biogel, HTP No.9112, was obtained from Biorad. Acrylamide and $N, N^{\prime}$-methylene-bis-acrylamide were products of Fluka. Liver alcohol dehydrogenase and pancreas trypsin were obtained from Boehringer Mannheim. Rabbit antitotal bovine serum-antiserum was obtained from the Central Laboratory of the Netherlands Red Cross. All other chemicals were of analytical grade and purchased from Merck.

Thromboplastin from bovine brain was prepared according to OWREN and AAS [33]. Phospholipid was isolated from the cephalin fraction of human brain according to MILSTONE [30] and suspended in veronal acetate buffer, $\mathrm{pH} 7.35$, to a concentration of $0.9 \mathrm{mg}$ protein per $\mathrm{ml}$ immediately before use. Factor-II reagent was prepared analogously to the method of KoLLER et al. [21], using bovine instead of human materials. Factor-VII reagent was prepared according to the method of LECHNER and DEUTSCH [24], as modified by SWART et al. [44]. Factor IX-deficient plasma was obtained from a patient with severe hemophilia B (factor IX: 1\%). Factor-X reagent was prepared either by adding a prepara-

${ }^{3}$ Abbreviations: DFP = diisopropylfluorophosphate; prep.p.a.a. = preparative polyacrylamide electrophoresis; PPSB = preparation containing prothrombin, proconvertin, Stuart-Power factor and antihemophilia factor B. 
tion of factors II and VII to $\mathrm{BaSO}_{4}$-adsorbed oxalated bovine plasma or by neutralizing and precipitating factor $\mathrm{X}$ from normal bovine plasma with a specific antiserum against bovine factor $\mathrm{X}$.

\section{Assay of Blood Coagulation Factors}

The activities of factors II, VII, and X were determined in one-stage assays as described for factor II by Koller et al. [2I]. Factor IX activity was estimated as described by VeLTKAMP et al. [46]. Factor Xa was determined as described by De LANGE and HemKer [23]. Normal bovine plasma was obtained after centrifugation of blood $(15 \mathrm{~min}, 1,000 \mathrm{~g}$; and 30 $\min , 1,500 \mathrm{~g}$ ) drawn into one-tenth by volume of trisodium citrate, $0.14 \mathrm{M}$. Hematocrit values were about $40 \%$. It is defined that $1 \mathrm{ml}$ of normal bovine plasma with a coagulation factor activity of $100 \%$ contains $1 \mathrm{U}$ of activity of each of the factors II, VII, IX or X.

\section{Initial Steps of Purification Procedure}

After adsorption of factors II, VII, IX and X from bovine citrated plasma onto aluminum hydroxide ( $1 \%$ final concentration) at $4{ }^{\circ} \mathrm{C}$, the adsorbent was washed with $\mathrm{Na}$ EDTA, $0.3 \mathrm{M}, \mathrm{pH} 8.0$; and Na-citrate, $0.1 \mathrm{M}, \mathrm{pH}$ 8.0. The factors were eluted from the adsorbent with phosphate buffer, $0.25 \mathrm{M}, \mathrm{pH} 8.0$ [44], and concentrated by ammonium sulfate precipitation between 35 and $65 \%$ saturation. For factors II and X, a 200 -fold purification was obtained at a yield of approximately $30 \%$. For factors VII and IX, the yield and purification were considerably higher, probably due to activation of these factors. The ammonium sulfate concentrate was dialyzed against $0.02 \mathrm{M} \mathrm{K}$-phosphate $+0.1 \mathrm{M} \mathrm{NaCl}+$ DFP, $0.1 \mathrm{~mm}$, pH 6.8 .

This preparation was called PPSB-2, and was used for separation of coagulation factors II, VII, IX and X by anion exchange chromatography.

\section{Chromatography}

All chromatographic procedures were performed at $4{ }^{\circ} \mathrm{C}$. The buffers contained DFP, $0.1 \mathrm{~mm}$. DEAE Sephadex was equilibrated in potassium phosphate buffer, $0.02 \mathrm{M}, \mathrm{pH}$ $6.8+\mathrm{NaCl}, 0.1 \mathrm{M}$. DEAE cellulose was equilibrated with potassium phosphate buffer, $0.05 \mathrm{M}, \mathrm{pH}$ 6.8. Conditions for elution of coagulation factor activity are described in the legends to the figures.

Gel filtration on Sephadex G-100 was done in Pharmacia K 25/100 columns, using phosphate buffer, $0.2 \mathrm{M}, \mathrm{pH} 6.8$, at a flow rate of $3-6 \mathrm{ml} / \mathrm{cm}^{2} / \mathrm{h}$. Assuming a linear relation between the logarithm of the molecular weight and the elution volume of the protein [1], estimation of molecular weights was done on G-100 columns precalibrated with dextran blue 2000, liver alcohol dehydrogenase, egg albumin, pancreas trypsin and cytochrome c.

Hydroxylapatite was equilibrated in potassium phosphate buffer, $0.075 \mathrm{M}, \mathrm{pH} 6.8$. On the column, a linear gradient was established to potassium phosphate, $0.5 \mathrm{M}, \mathrm{pH} 6.8$. Before application to the hydroxylapatite column, the samples were made $0.075 \mathrm{M}$ in phosphate.

Protein contents were estimated after LowRy et al. [26], or by measuring the extinction at $280 \mathrm{~nm}$ (Zeiß PMQ II spectrophotometer). Immunoelectrophoresis was performed according to SCHEIDEGGER [39] on microscope slides.

Column effluents were analyzed conductometrically with the LKB Conductolyzer. Concentration of protein samples was done in Amicon ultrafiltration cells using UM-10 
membranes. The UV absorbancies of column effluents were measured with the aid of an LKB Uvicord II monitor.

\section{Polyacrylamide Electrophoresis}

Analytical polyacrylamide electrophoresis was performed according to DAVIS [10], using a 7.5-percent gel of $2.8 \%$ cross-linking. Amido black was used for protein staining. Glycoproteins were stained with PAS reagent, according to KeYZER [20]. Lipoproteins were stained with Sudan orange III, according to PrATT and DANGERFIELD [37].

Prep. p. a. a. was performed in a 7-percent separating gel, $2.8 \%$ cross-linking, using the Quickfit 'Prep Page' equipment. As a buffer system, borate buffer according to GoRDON and LouIs [15] was used. Bromophenol blue served as a tracking dye. The elution buffer did not contain DFP.

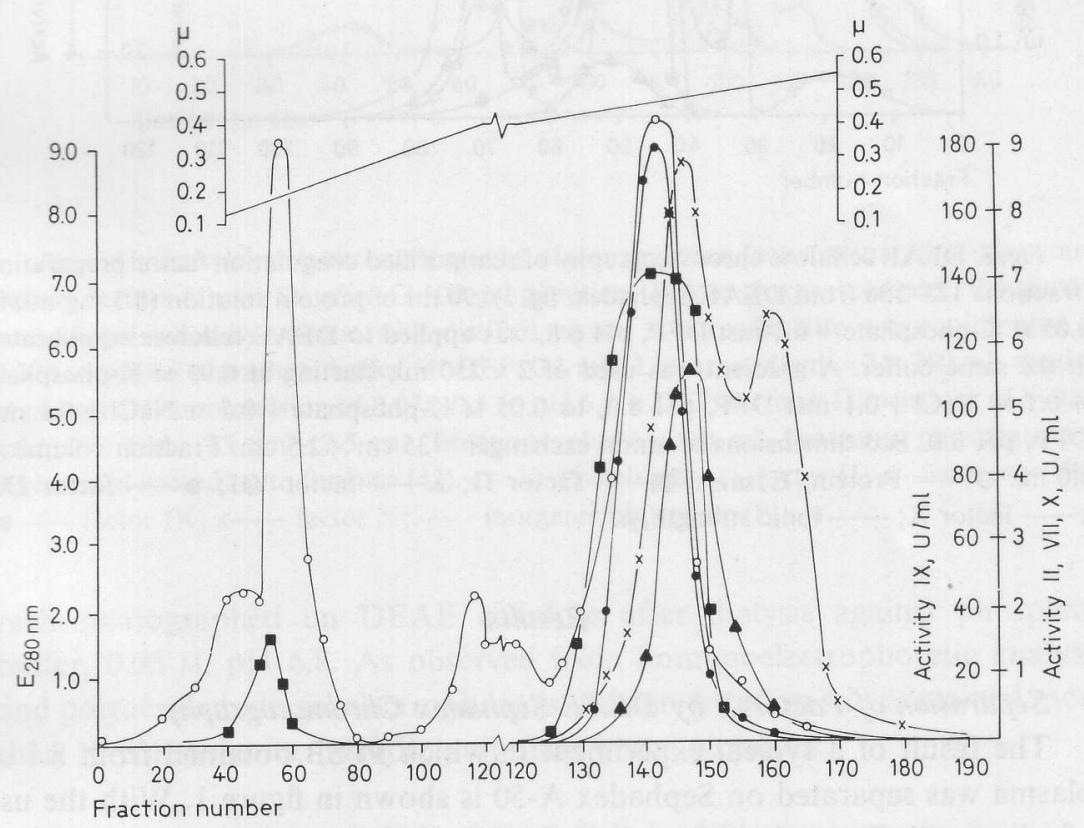

Fig. 1. DEAE Sephadex chromatography of PPSB-2 in 0.02 м K-phosphate $+0.1 \mathrm{~m}$ $\mathrm{NaCl}+0.1 \mathrm{~mm}$ DFP, pH $6.8 .70 \mathrm{ml}$ of protein solution $(21 \mathrm{mg} / \mathrm{ml})$ was applied. After $50 \mathrm{ml}$ of effluent had been collected, a gradient of $2 \times 350 \mathrm{ml}$ was started, ranging from $0.02 \mathrm{~K}$-phosphate $+0.1 \mathrm{M} \mathrm{NaCl}$ to $0.02 \mathrm{M} \mathrm{K}$-phosphate $+1 \mathrm{M} \mathrm{NaCl}+0.1 \mathrm{~mm} \mathrm{DFP,} \mathrm{pH} 6.8$. Fraction volume $=2.8 \mathrm{ml}$. Bed dimensions of anion exchanger $=35 \mathrm{~cm} \times 2.5 \mathrm{~cm}$.

O_Protein, $E_{2} 80 \mathrm{~nm}$; factor-II activity; factor-VII activity; -factorIX activity; $\mathrm{x}-$ factor-X activity; - ionic strength, $\mu$. 


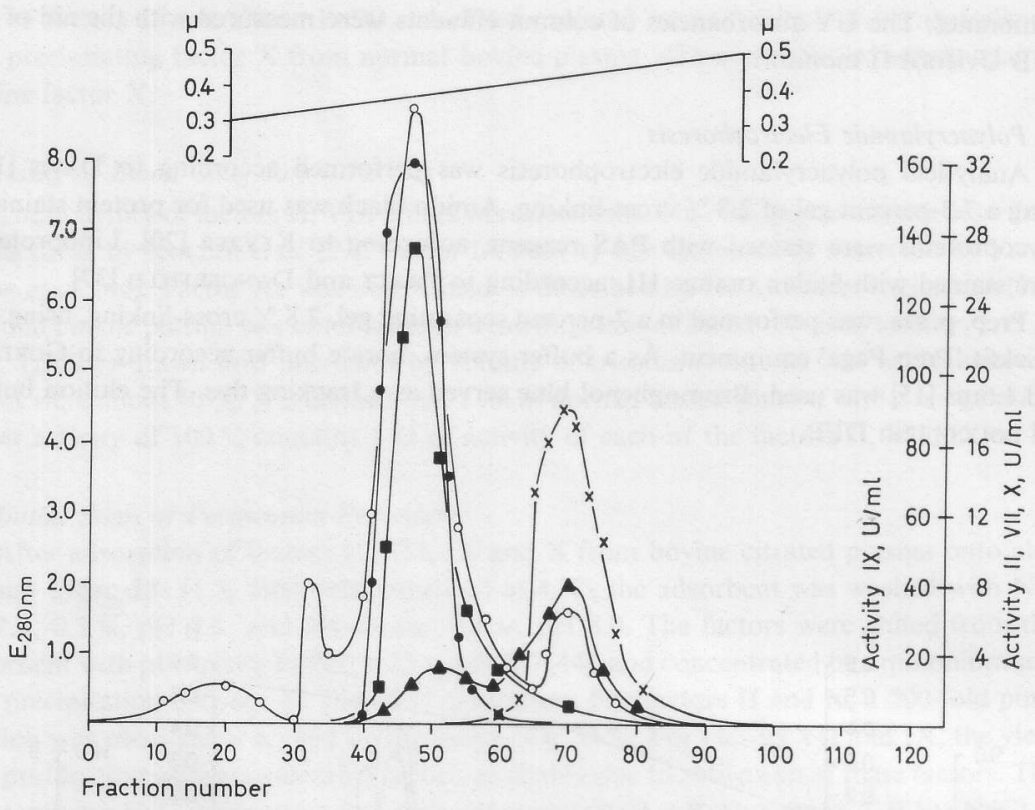

Fig. 2. DEAE cellulose chromatography of semipurified coagulation factor preparation (fractions 125-156 from DEAE Sephadex, fig. 1). $90 \mathrm{ml}$ of protein solution $(8.3 \mathrm{mg} / \mathrm{ml}$ ) in 0.05 м K-phosphate +0.1 mм DFP, $\mathrm{pH}$ 6.8, was applied to DEAE cellulose equilibrated in the same buffer. A gradient was used of $2 \times 250 \mathrm{ml}$, starting at $0.05 \mathrm{M} \mathrm{K}$-phosphate $+0.1 \mathrm{M} \mathrm{NaCl}+0.1 \mathrm{~mm}$ DFP, $\mathrm{pH} 8.0$, to $0.05 \mathrm{M} \mathrm{K}$-phosphate $+0.5 \mathrm{M} \mathrm{NaCl}+0.1 \mathrm{~mm}$ DFP, $\mathrm{pH}$ 8.0. Bed dimensions of anion exchanger $=35 \mathrm{~cm} \times 2.5 \mathrm{~cm}$. Fraction volume $=$ $4.0 \mathrm{ml}$. $\mathrm{O}-$ Protein, E $280 \mathrm{~nm}$; - factor II; $\_$factor VII; $\bullet-$ factor IX;
$\mathrm{x}-$ factor X; $\longrightarrow$ ionic strength, $\mu$.

\section{Results}

Separation of Factor $X$ by DEAE Sephadex Chromatography

The result of a typical experiment in which PPSB obtained from 81 of plasma was separated on Sephadex A-50 is shown in figure 1. With the use of a linear $\mathrm{NaCl}$ gradient, factors II and IX were eluted at an ionic strength, $\mu=0.48$, and factor VII at $\mu=0.50$. Factor-X activity was eluted both at $\mu=0.50$ and 0.57 . By coagulation factor assays, the first peak of factor-X activity was shown to coincide with factor $\mathrm{X}_{\mathrm{a}}$ and the second peak with factor X. This second peak (fractions 157-180) served as a source for preparing pure factor $\mathrm{X}$ by procedures to be described later. For further purification of factors II, VII, and IX, fractions 125-156 were pooled and 


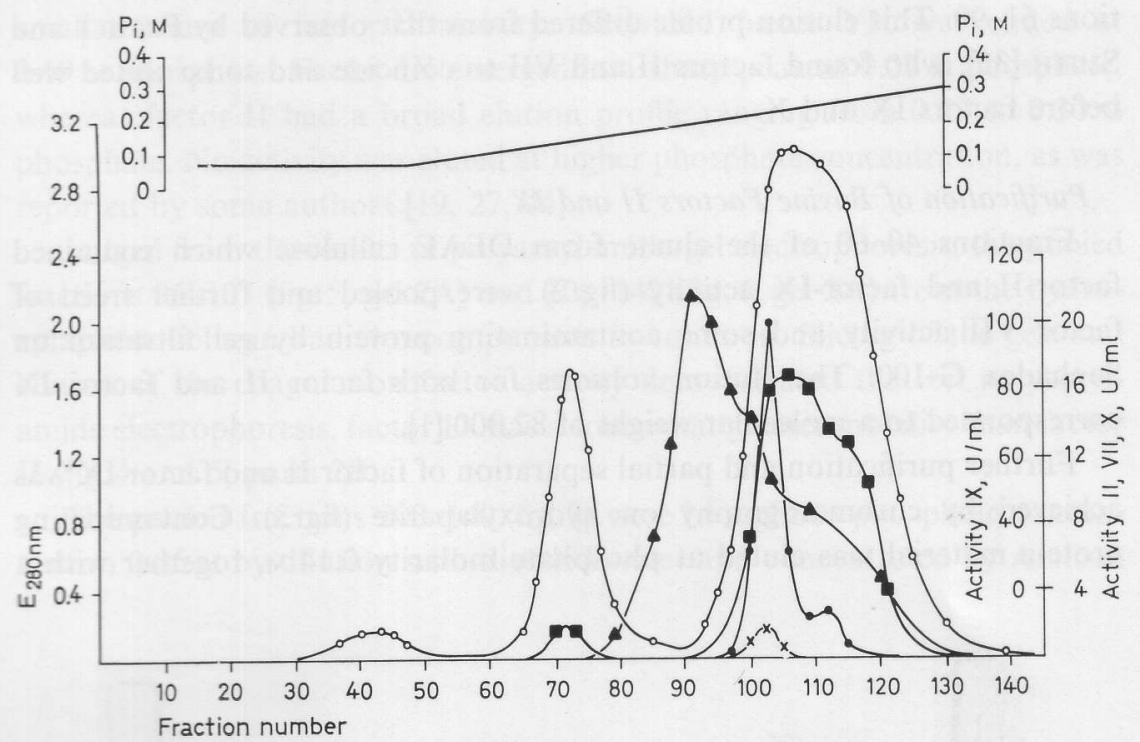

Fig. 3. Hydroxylapatite chromatography of a coagulation factor preparation containing mainly factors II and IX after G-100 gel filtration. Before chromatography, the sample was diluted twice its volume with distilled water. Hydroxylapatite was equilibrated in $0.075 \mathrm{M}, \mathrm{pH} 6.8$ phosphate buffer, + DFP, $0.1 \mathrm{~mm}$. Linear gradient $=2 \times 200 \mathrm{ml}$, starting at phosphate concentration of $0.075-0.5 \mathrm{M}, \mathrm{pH} 6.8+$ DFP, $0.1 \mathrm{~mm}$. Dimensions of hydroxylapatite bed $=25 \mathrm{~cm} \times 2.5 \mathrm{~cm}$. Fraction volume $=4.0 \mathrm{ml}$. Inorganic phosphate was determined according to SUMNER [42]. O— Protein; factor II; $\_$- factor VII; - factor IX; $\mathrm{x}$ - factor X; — inorganic phosphate (Pi), M.

rechromatographed on DEAE cellulose after dialysis against phosphate buffer, $0.05 \mathrm{M}, \mathrm{pH}$ 6.8. As observed from immunoelectrophoretic analysis and polyacrylamide-gel electrophoresis, this preparation still contained more than 10 components, including albumin and $\beta$-globulins.

\section{Separation of Factor VII by DEAE Cellulose Chromatography}

Figure 2 shows that rechromatography on DEAE cellulose of a semipurified coagulation factor preparation (fractions 125-156, fig. 1) resulted in elution of factors II and IX at ionic strength $\mu=0.38$. The greater part of factor-VII activity was found to emerge from the column at $\mu=0.44$, coinciding with factor-X activity. The main protein peak (fractions 40-60) served as a source of factors II and IX; factor VII was further purified from frac- 
tions 61-90. This elution profile differed from that observed by PECHET and SмIтH [35], who found factors II and VII to coincide and to be eluted well before factors IX and $\mathrm{X}$.

\section{Purification of Bovine Factors II and IX}

Fractions 40-60 of the eluate from DEAE cellulose which contained factor-II and factor-IX activity (fig.2) were pooled and further freed of factor VII activity and some contaminating protein by gel filtration on Sephadex G-100. The elution volumes for both factor II and factor IX corresponded to a molecular weight of 82,000 [1].

Further purification and partial separation of factor II and factor IX was achieved by chromatography on hydroxylapatite (fig.3). Contaminating protein material was eluted at phosphate molarity $0.14 \mathrm{M}$, together with a

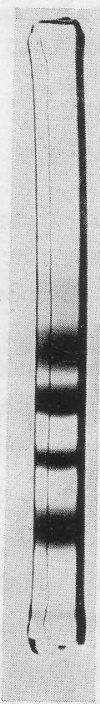

(1)

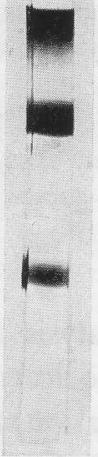

(2A)

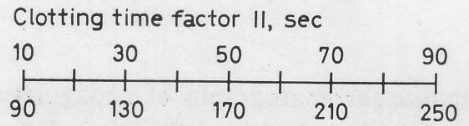

Clotting time factor $1 X$, sec

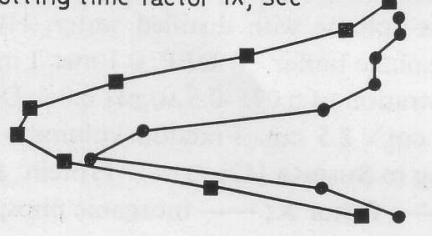

(2B)

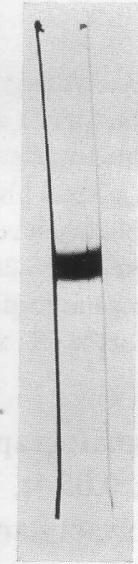

(3)

Fig.4. Analytical polyacrylamide electrophoresis. Gel 1: fractions 40-60 after DEAE cellulose (fig. 2) containing factors II, VII, and IX; $150 \mu \mathrm{g}$ protein. Gel 2A: fractions 108-140 after hydroxylapatite (fig. 3), containing mainly factor-II activity, contaminated with factors VII and IX; $300 \mu \mathrm{g}$ protein. Gel $2 \mathrm{~B}$ : factor-II and IX assays in $0.5-\mathrm{cm}$ slices of a gel, run parallel to gel $2 \mathrm{~A}$ with the same sample. Extraction of coagulation factor activity with $0.5 \mathrm{ml}$ of veronal acetate buffer, $\mathrm{pH}$ 7.4. Horizontally: clotting times; vertically: excised part of the gel. Gel 3: fractions $95-104$ after prep.p.a.a. (fig. 6), containing only factor-II activity. factor IX. 
small amount of factor-II activity. Activated factor VII was eluted at $0.19 \mathrm{M}$ phosphate. Factor IX emerged in a sharp peak at $0.22 \mathrm{M}$ phosphate, whereas factor II had a broad elution profile ranging from 0.22 to $0.30 \mathrm{M}$ phosphate. No activity was eluted at higher phosphate concentration, as was reported by some authors $[19,27,44]$.

Judged from the results of polyacrylamide-gel electrophoresis, the pooled fractions 96-107 (fig. 5, gel 2A) and 108-140 (fig. 4, gel 2A) from the hydroxylapatite column had two components in common. Slicing of the gels and elution of the coagulation factor activity demonstrated that on polyacrylamide electrophoresis, factor IX has a somewhat greater mobility than factor II (fig. 4 and 5, parts 2B).

The pooled fractions 108-140 (fig. 3) were brought to phosphate concentration $0.05 \mathrm{M}$ by dilution with distilled water and concentrated by Amicon

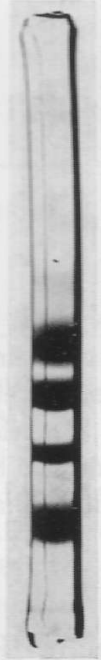

(1)

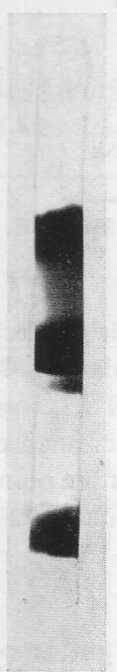

(2A)

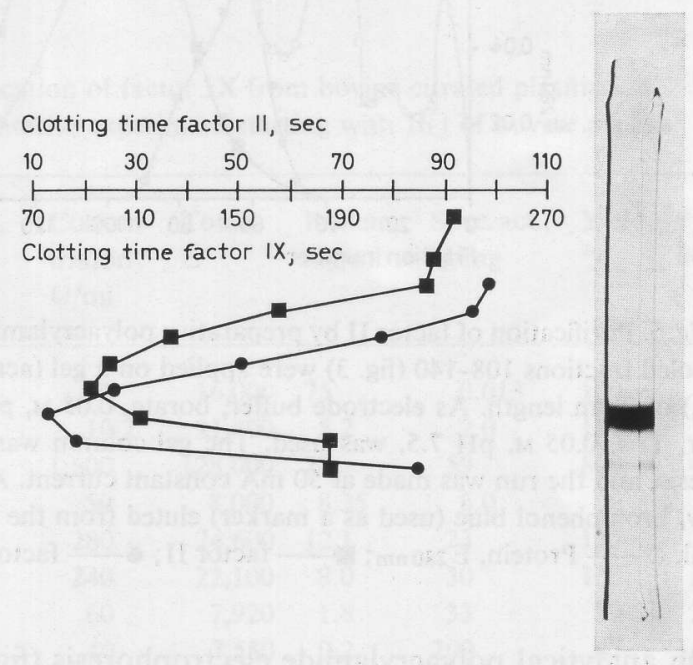

(2B)
(3)

Fig.5. Analytical polyacrylamide electrophoresis. Gel 1: fractions 40-60 after DEAE cellulose (fig. 2) containing factors II, VII, and IX; $150 \mu \mathrm{g}$ protein. Gel 2A: fractions 96-107 after hydroxylapatite (fig. 3), containing mainly factors IX and II; $100 \mu \mathrm{g}$ protein. Gel 2B: factor-II and factor-IX assays in $0.5-\mathrm{cm}$ slices of a gel, run parallel to gel $2 \mathrm{~A}$ with the same sample. Extraction of coagulation factor activity with $0.5 \mathrm{ml}$ of veronal acetate buffer, $\mathrm{pH}$ 7.4. Horizontally: clotting times; vertically: excised part of the gel. Gel 3 : factor-IX preparation after prep. p.a.a., contaminated with factor II (about $10 \%$ ). घ- Factor II; factor IX. 
UM-10 membrane filtration. This sample was submitted to preparative polyacrylamide electrophoresis. As is shown in figure 6, factor IX was found to be eluted before factor II. Polyacrylamide electrophoresis gave an extensive loss of factor-II activity. Apart from factors IX and II, at least two other proteins could be detected in the protein pattern. No factor VI or thrombin was found in the eluted protein peaks. Fractions 95-104 were pooled and injected into rabbits to obtain an antiserum against bovine factor II [38]. Fractions 60-94 were pooled and used for the adsorption from the antiserum of those antibodies not directed against bovine prothrombin.

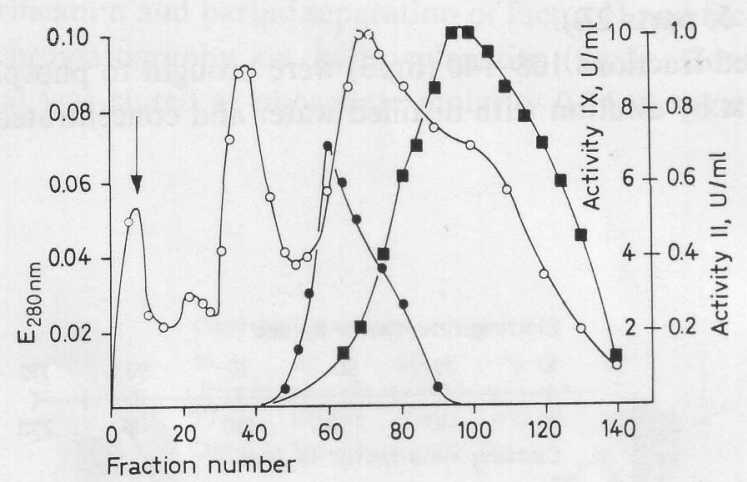

Fig.6. Purification of factor II by preparative polyacrylamide gel electrophoresis. $10 \mathrm{ml}$ of pooled fractions 108-140 (fig. 3) were applied on a gel (acrylamide, $7 \%$; cross-linking,

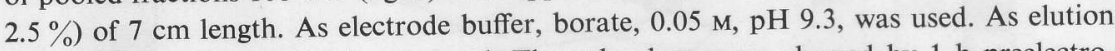
buffer, Tris, $0.05 \mathrm{M}, \mathrm{pH} 7.5$, was used. The gel column was cleaned by $1 \mathrm{~h}$ preelectrophoresis, and the run was made at $50 \mathrm{~mA}$ constant current. At the point indicated by the arrow, bromphenol blue (used as a marker) eluted from the column. Fraction volume $=$ $2.8 \mathrm{ml}$. factor II; factor IX.

On analytical polyacrylamide electrophoresis (fig. 4, gel 3), factor-II preparation showed one main band, containing factor-II activity, and a minor, more anodal band, which apparently had no coagulation factor activity. Staining of the gels with PAS reagent demonstrated that the main band contained glycoprotein. The gels could not be stained with Sudan orange III.

Table I shows the overall result of the purification procedure for factor II from bovine plasma in a representative experiment. In a set of five experiments, the results were always qualitatively equal, but large variations were observed in the overall yield of factor II after hydroxylapatite chromatography (between 2 and $14 \%$ ) and prep. p.a.a. (between 0.5 and $3 \%$ ). 
e polyund to tensive other rombin ed and II [38]. iserum
5. $10 \mathrm{ml}$ linking, elution electroby the lume $=$

I preninor, tivity. band ge III. tor II xperiwere mato-

Table I. Purification of factor II from bovine plasma.

Results of a representative experiment starting with 161 of bovine plasma

\begin{tabular}{|c|c|c|c|c|c|c|c|}
\hline Fraction & $\begin{array}{l}\text { Volume, } \\
\mathrm{ml}\end{array}$ & $\begin{array}{l}\text { Concen- } \\
\text { tration, } \\
\mathrm{U} / \mathrm{ml}\end{array}$ & $\begin{array}{l}\text { Total, } \\
\mathrm{U}\end{array}$ & $\begin{array}{l}\text { Protein, } \\
\mathrm{mg} / \mathrm{ml}\end{array}$ & $\begin{array}{l}\text { Spec. act., } \\
\text { U/mg }\end{array}$ & $\begin{array}{l}\text { Yield, } \\
\%\end{array}$ & $\begin{array}{l}\text { Puri- } \\
\text { fication }\end{array}$ \\
\hline Plasma & 16,000 & 1 & 16,000 & 75 & 0.013 & 100 & 1 \\
\hline PPSB-1 & 2,140 & 4.20 & 8,990 & 5.2 & 0.81 & 56 & 60 \\
\hline PPSB-2 & 80 & 60 & 4,800 & 27 & 2.23 & 30 & 170 \\
\hline DEAE Sephadex & 160 & 28 & 3,480 & 8.4 & 3.35 & 22 & 260 \\
\hline DEAE cellulose & 88 & 35 & 3,080 & 12.1 & 3.64 & 19 & 280 \\
\hline$G-100$ & 92 & 24 & 2,200 & 8.0 & 3.0 & 14 & 230 \\
\hline Hydroxylapatite & 132 & 12 & 1,584 & 0.95 & 12.8 & 10 & 960 \\
\hline Prep. p.a.a. & 504 & 0.7 & 358 & 0.08 & 8.75 & 2.5 & 640 \\
\hline
\end{tabular}

Table II. Purification of factor IX from bovine citrated plasma.

Results of a representative experiment starting with 161 of bovine plasma

\begin{tabular}{|c|c|c|c|c|c|c|c|}
\hline Fraction & $\begin{array}{l}\text { Volume, } \\
\mathrm{ml}\end{array}$ & $\begin{array}{l}\text { Concen- } \\
\text { tration } \\
\mathrm{U} / \mathrm{ml}\end{array}$ & $\begin{array}{l}\text { Total, } \\
\text { U }\end{array}$ & $\begin{array}{l}\text { Protein, } \\
\mathrm{mg} / \mathrm{ml}\end{array}$ & $\begin{array}{l}\text { Spec.act., } \\
\mathrm{U} / \mathrm{mg}\end{array}$ & $\begin{array}{l}\text { Yield, } \\
\%\end{array}$ & $\begin{array}{l}\text { Puri- } \\
\text { fication }\end{array}$ \\
\hline Plasma & 16,000 & 1 & 16,000 & 75 & 0.013 & 100 & 1 \\
\hline PPSB-1 & 2,140 & 10.2 & 21,800 & 5.2 & 2.0 & 136 & 150 \\
\hline PPSB-2 & 80 & 1,600 & 128,000 & 27 & 59 & 800 & 4,550 \\
\hline DEAE Sephadex & 160 & 50 & 8,000 & 8.35 & 6.0 & 50 & 460 \\
\hline DEAE cellulose & 88 & 280 & 24,600 & 12.1 & 23 & 155 & 1,780 \\
\hline $\mathrm{G}-100$ & 92 & 240 & 22,100 & 8.0 & 30 & 138 & 2,310 \\
\hline Hydroxylapatite & 132 & 60 & 7,920 & 1.8 & 33 & 50 & 2,540 \\
\hline Prep. p.a.a. & 188 & 40 & 7,530 & 0.2 & 200 & 47 & 15,400 \\
\hline
\end{tabular}

Separation of factor IX from contaminating factor-II activity, as found in fractions 96-107 from the hydroxylapatite column (fig. 3), was achieved by prep. p.a.a. Factor IX migrated faster than factor II, as had been observed also for prep. p.a.a. of a factor-II preparation (fig. 6). As is shown in figure 5, gel 3, fractions with maximal factor-IX activity showed one main protein band on analytical polyacrylamide electrophoresis, this band coinciding with factor-IX activity, and being stainable with PAS reagent. These fractions 
were used to obtain antibodies against factor IX in rabbits [38]. A minor contamination (about $10 \%$ ) with possibly factor-II activity was observed.

Table II shows the overall result of the purification procedure for factor IX from bovine plasma in a representative experiment. The high yield and purification are undoubtedly due to activation of factor IX during the purification procedure.

\section{Purification and Isolation of Bovine Factor VII}

Isolation of factor VII started from fractions 61-90 from DEAE cellulose chromatography (fig. 2). Considerable purification of factor VII was achieved by gel filtration on G-100. The elution volume for factor VII corresponded to a molecular weight of about 68,000 . No factor-II or factor-IX activity was observed. The fractions having maximal factor-VII activity were pooled, concentrated and used for further purification by hydroxylapatite.

As is demonstrated in figure 7, factor VII was eluted at a phosphate concentration of $0.19 \mathrm{M}$, whereas the main portion of protein material was

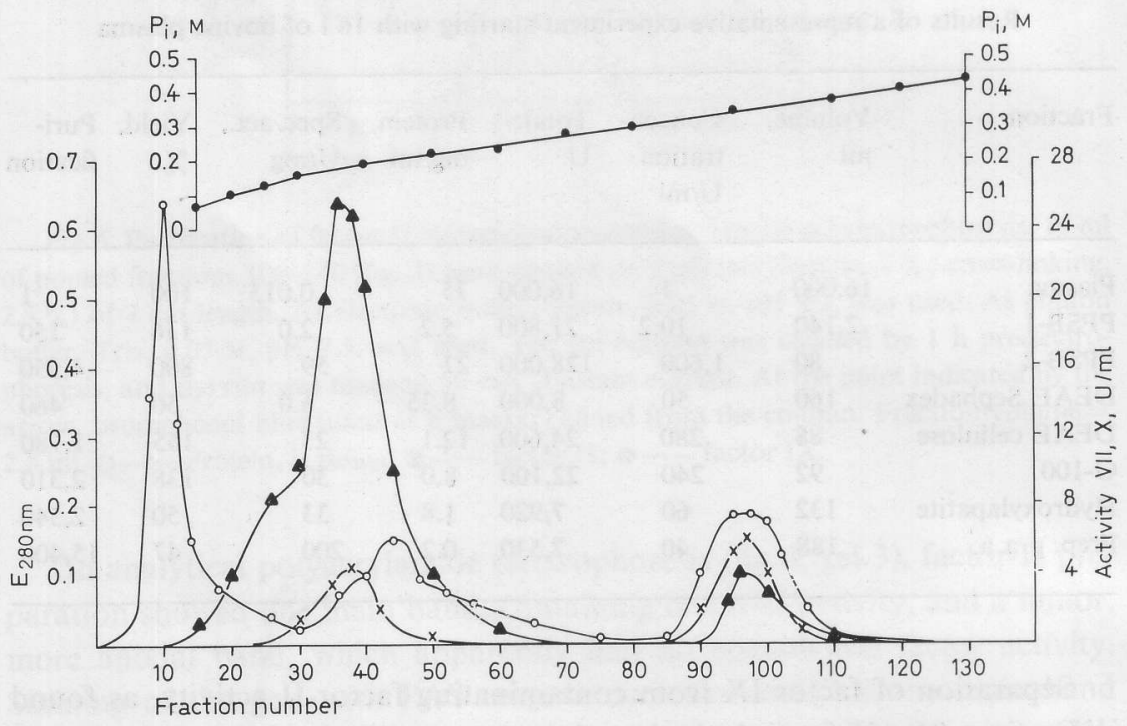

Fig.7. Hydroxylapatite chromatography of factor-VII preparation obtained after G-100 gel filtration. $30 \mathrm{mg}$ of protein material was applied in $0.075 \mathrm{M}, \mathrm{pH} 6.8$ phosphate buffer + DFP, $0.1 \mathrm{~mm}$. Linear gradient: $2 \times 150 \mathrm{ml}$ phosphate, $0.075-0.5 \mathrm{M}$, pH 6.8 + DFP, $0.1 \mathrm{~mm}$. Column dimensions $=30 \mathrm{~cm} \times 1.5 \mathrm{~cm}$. Flow rate $=2 \mathrm{ml} / \mathrm{cm}^{2} / \mathrm{h}$. Fraction volume $=2.8 \mathrm{ml}$. O— Protein, E $280 \mathrm{~nm}$; factor VII; $\mathrm{x} \longrightarrow$ factor $\mathrm{X}$; phosphate concentration. 
minor served. factor eld and e puri-

ellulose chieved nded to ty was ooled, sphate al was

not retarded on hydroxylapatite at the starting phosphate concentration $(0.075 \mathrm{M})$. The elution profile of factor-VII activity did not coincide with the protein elution profile, indicating that factor VII was still contaminated with other protein material.

On analytical polyacrylamide electrophoresis (fig. 8 , gel 2), the main protein band had factor-VII activity and it could be faintly stained with PAS reagent. Another minor, more anodal protein band was observed, the nature of which could not be determined. The factor-VII band corresponded well with the band representing factor-VII activity in the pooled fractions $61-90$ from the DEAE cellulose column (fig. 8, gels 1A and B).

So little material was left after the many stages of the purification procedure that pooled fractions 31-40 after hydroxylapatite chromatography (fig.7) were used as a factor-VII preparation, although analytical polyacrylamide electrophoresis suggested that further purification was still possible. The preparation was used for immunizing rabbits to obtain an antiserum against bovine factor VII.

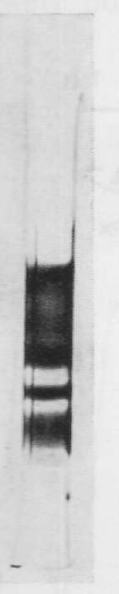

(1A)
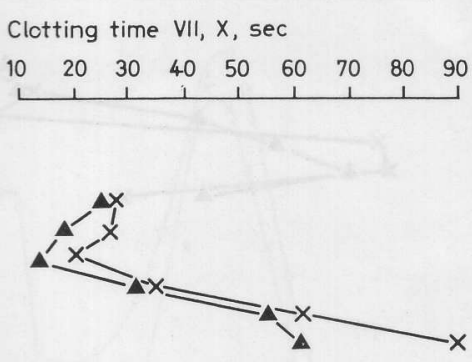

(1B)

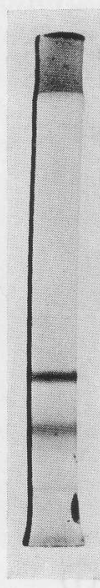

(2)

Fig.8. Analytical polyacrylamide-gel electrophoresis. Gel 1A fractions 61-90 (fig. 2) after DEAE cellulose chromatography containing factors VII and X; $130 \mu \mathrm{g}$ protein. Gel 1B: factor-VII and factor-X assays in slices of a gel, run parallel to gel $1 \mathrm{~A}$ with the same sample. Length of slices $=0.5 \mathrm{~cm}$. Extraction of coagulation factor activity from the gels with $0.5 \mathrm{ml}$ veronal acetate buffer, $\mathrm{pH} 7.4$. Horizontally: clotting times; vertically: excised part of the gel. Gel 2: fractions 31-40 (fig. 7) after hydroxylapatite chromatography; $40 \mu \mathrm{g}$ protein. Factor VII; $\mathrm{x}-$ factor $\mathrm{X}$. 
Table III. Purification of factor VII from bovine citrated plasma.

Results of a representative experiment starting from 161 of bovine plasma

\begin{tabular}{|c|c|c|c|c|c|c|c|}
\hline Fraction & $\begin{array}{l}\text { Volume, } \\
\mathrm{ml}\end{array}$ & $\begin{array}{l}\text { Concen- } \\
\text { tration, } \\
\mathrm{U} / \mathrm{ml}\end{array}$ & $\begin{array}{l}\text { Total, } \\
\text { U }\end{array}$ & $\begin{array}{l}\text { Protein, } \\
\mathrm{mg} / \mathrm{ml}\end{array}$ & $\begin{array}{l}\text { Spec. act., } \\
\mathrm{U} / \mathrm{mg}\end{array}$ & $\begin{array}{l}\text { Yield, } \\
\%\end{array}$ & $\begin{array}{l}\text { Puri- } \\
\text { fication }\end{array}$ \\
\hline Plasma & 16,000 & 1 & 16,000 & 75 & 0.013 & 100 & 1 \\
\hline PPSB-1 & 2,140 & 5.83 & 12,470 & 5.2 & 1.1 & 77 & 86 \\
\hline PPSB-2 & 80 & 51 & 4,080 & 27 & 1.9 & 26 & 145 \\
\hline DEAE Sephadex & 160 & 18 & 2,880 & 8.4 & 2.2 & 18 & 166 \\
\hline DEAE cellulose & 128 & 12.5 & 1,600 & 2.5 & 5.0 & 10 & 385 \\
\hline G-100 & 35 & 18.5 & 650 & 0.6 & 31.0 & 4 & 2,380 \\
\hline Hydroxylapatite & 28 & 18.0 & 500 & 0.1 & 180 & 3 & 14,000 \\
\hline
\end{tabular}

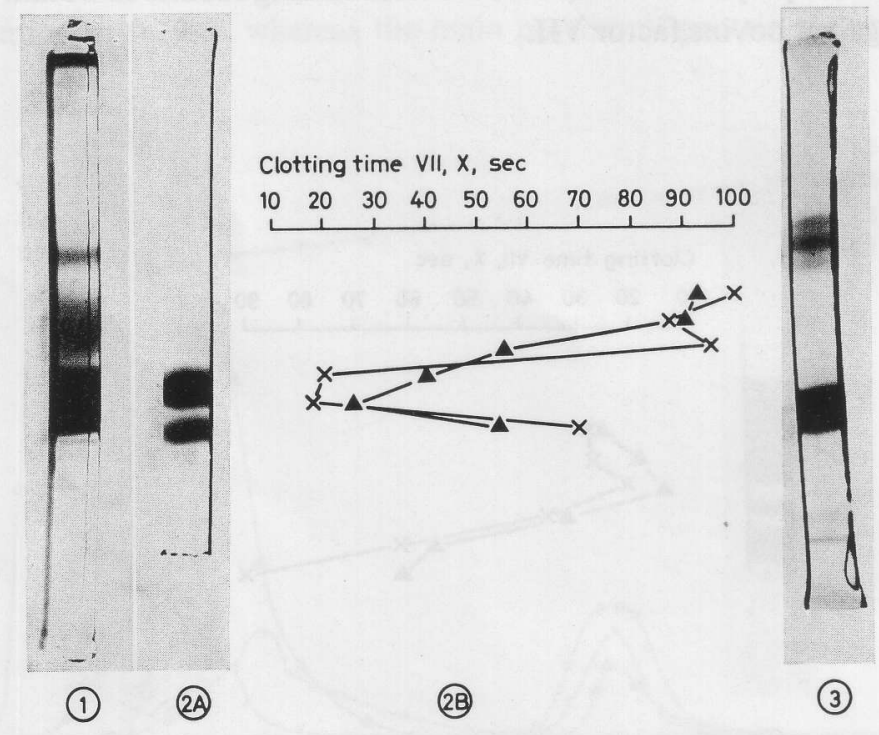

Fig.9. Analytical polyacrylamide-gel electrophoresis. Gel 1: fractions 157-180 (fig. 1) after DEAE Sephadex chromatography, containing factors VII and X; $230 \mu \mathrm{g}$ protein. Gel 2A: pooled fractions eluted from G-100 between $175-210 \mathrm{ml}$ (fig. 10); $110 \mu \mathrm{g}$ protein. Gel 2B: factor-VII and factor-X assays in $0.5-\mathrm{cm}$ slices of a gel (ordinate), run parallel to gel $2 \mathrm{~A}$ with the same sample. Extraction of coagulation factor activity with $0.5 \mathrm{ml}$ veronal acetate buffer, $\mathrm{pH}$ 7.4. Horizontally: clotting times; vertically; excised part of the gel. Gel 3: fractions 45-60 after hydroxylapatite chromatography (fig. 11); $125 \mu \mathrm{g}$ protein. $\triangle$ Factor VII; $\mathrm{X}$ - factor $\mathrm{X}$. 
Table III shows the result of the purification procedure for factor VII from bovine plasma in a representative experiment. The overall yield was $3 \%$ and a purification of $14,000-$ fold was reached.

Purification

\section{Purification and Isolation of Bovine Factor $X$}

Fractions 157-180 from DEAE Sephadex chromatography (fig. 1) served as a starting material for the isolation of factor $\mathrm{X}$, as previously reported by JACKSON et al. [18]. The material contained some factor-VII activity as well. Polyacrylamide electrophoresis revealed the presence of at least four protein bands; the position of the main protein band correlated well with the position where maximal factor- $X$ activity was found in sliced gels (fig. 9, gels 1 and $2 b$ ).

G-100 gel filtration of this preparation resulted in poor separation of factor X from the contaminating factor-VII activity (fig. 10). Considerable separation of factor $\mathrm{X}$ from other proteins emerging near the void volume was obtained.

From the elution volume of factor-X activity, a molecular weight of about 84,000 was calculated. The fractions between the elution volumes $175-210 \mathrm{ml}$ were pooled. On polyacrylamide-gel electrophoresis, this pre-

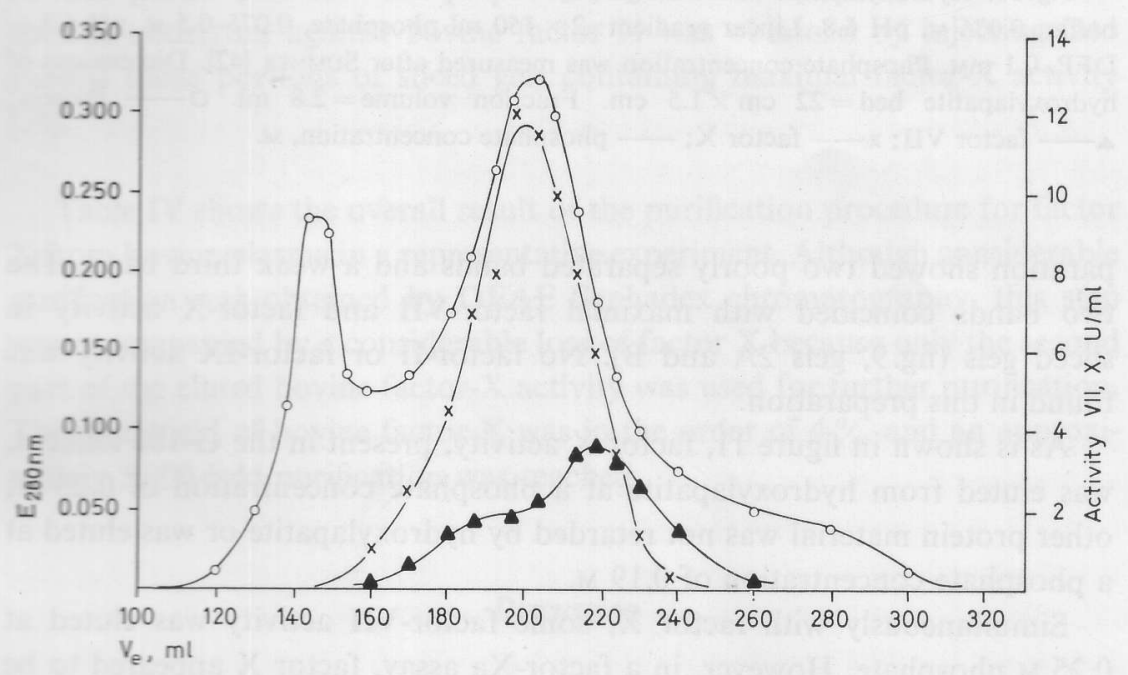

Fig.10. G-100 gelfiltration in phosphate buffer, $0.2 \mathrm{~m}$, pH $6.8+$ DFP, $0.1 \mathrm{~mm}$, of fractions $157-180$ after DEAE Sephadex (fig. 1). $5 \mathrm{ml}$ of protein solution $(3.8 \mathrm{mg} / \mathrm{ml})$ was applied. Dimensions of gel bed $=85 \mathrm{~cm} \times 2.5 \mathrm{~cm}$. Vo $=135 \mathrm{ml}$. Flow rate $=3.6 \mathrm{ml} / \mathrm{cm}^{2} / \mathrm{h}$.

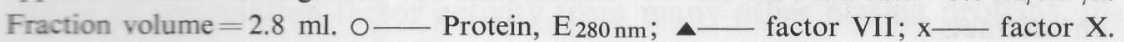




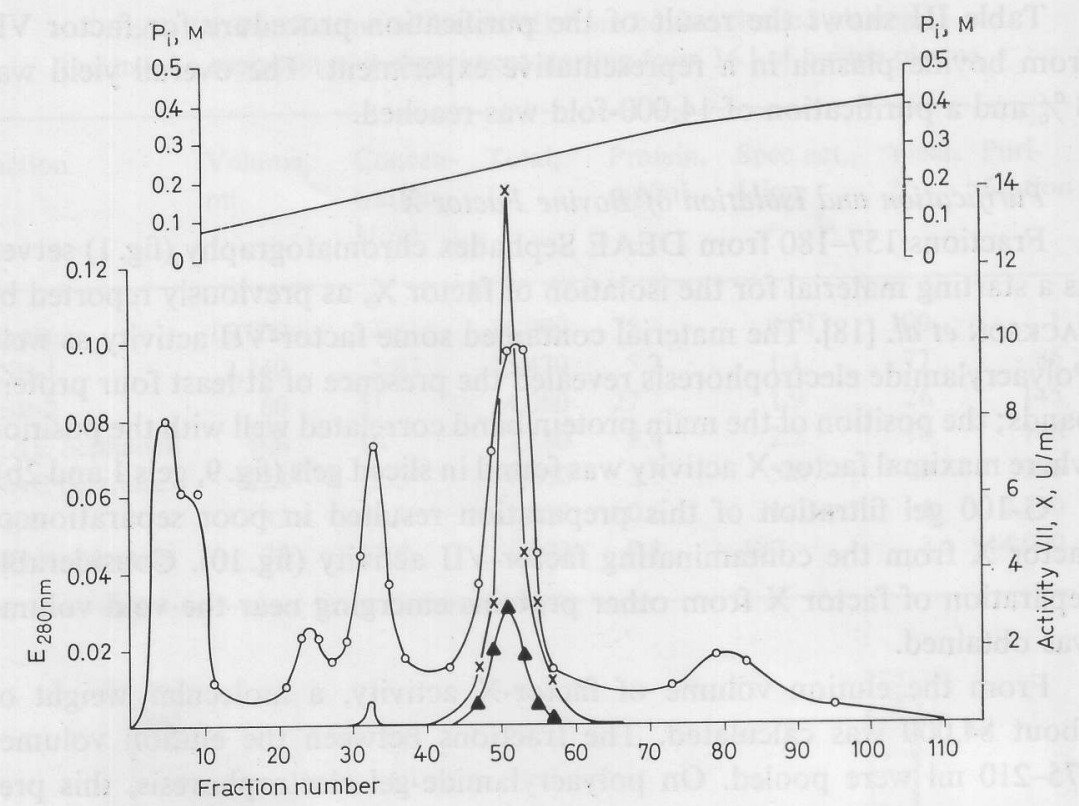

Fig. 11. Hydroxylapatite chromatography of fractions $175-210$ (fig. 10) in phosphate buffer, $0.075 \mathrm{M}$, pH 6.8. Linear gradient: $2 \times 150 \mathrm{ml}$ phosphate, $0.075-0.5 \mathrm{M}, \mathrm{pH} 6.8+$ DFP, $0.1 \mathrm{mM}$. Phosphate concentration was measured after SUMNER [42]. Dimensions of hydroxylapatite $\mathrm{bed}=22 \mathrm{~cm} \times 1.5 \mathrm{~cm}$. Fraction volume $=2.8 \mathrm{ml}$. O- Protein; $\triangle$ factor VII; $\mathrm{x}$ — factor X; —— phosphate concentration, $\mathrm{M}$.

paration showed two poorly separated bands and a weak third band. The two bands coincided with maximal factor-VII and factor-X activity in sliced gels (fig.9, gels $2 \mathrm{~A}$ and B). No factor-II or factor-IX activity was found in this preparation.

As is shown in figure 11, factor-X activity, present in the G-100 effluent, was eluted from hydroxylapatite at a phosphate concentration of $0.25 \mathrm{M}$; other protein material was not retarded by hydroxylapatite or was eluted at a phosphate concentration of $0.19 \mathrm{M}$.

Simultaneously with factor X, some factor-VII activity was eluted at $0.25 \mathrm{M}$ phosphate. However, in a factor-Xa assay, factor $\mathrm{X}$ appeared to be partly activated; consequently, shortening of clotting time in a factor-VII assay may be expected. The complete coincidence and constant fractional ratio of factors VII and $\mathrm{X}$ argued in favor of this factor-VII activity to be an artefact. 
Table IV. Purification of factor $\mathrm{X}$ from bovine citrated plasma.

Results of a representative experiment starting from 161 of bovine plasma

\begin{tabular}{lrlllllrr}
\hline & $\begin{array}{l}\text { Volume, } \\
\text { ml }\end{array}$ & $\begin{array}{l}\text { Concen- } \\
\text { tration, } \\
\text { U/ml }\end{array}$ & $\begin{array}{l}\text { Total, } \\
\text { U }\end{array}$ & $\begin{array}{l}\text { Protein, } \\
\mathrm{mg} / \mathrm{ml}\end{array}$ & $\begin{array}{l}\text { Spec.act., } \\
\mathrm{U} / \mathrm{mg}\end{array}$ & $\begin{array}{l}\text { Yield, } \\
\%\end{array}$ & $\begin{array}{l}\text { Puri- } \\
\text { fication }\end{array}$ \\
\hline Plasma & 16,000 & 1 & 16,000 & 75 & 0.013 & 100 & 1 \\
PPSB-1 & 2,140 & 5.3 & 11,310 & 5.2 & 1.0 & 70 & 78 \\
PPSB-2 & 80 & 72 & 5,740 & 27 & 2.7 & 36 & 205 \\
DEAE Sephadex & 70 & 12 & 840 & 0.4 & 30 & 7 & 2,300 \\
G-100 & 35 & 20 & 700 & 0.4 & 54 & 4 & 4,150 \\
Hydroxylapatite & 42 & 14 & 600 & 0.2 & 66 & 4 & 5,120 \\
\hline
\end{tabular}

On polyacrylamide gels, the factor-X preparation from the hydroxylapatite column revealed one main protein band having factor- $X$ activity (fig.9, gel 3); glycoprotein staining with PAS reagent gave a positive reaction at the same position as the main band observed after protein staining with amido black. Three minor, more cathodal contaminants were present. No further purification of this preparation was attempted, because monospecific antiserum against bovine factor $\mathrm{X}$ was obtained by injecting into rabbits those portions of sliced gels containing maximal factor-X activity [38].

Table IV shows the overall result of the purification procedure for factor $\mathrm{X}$ from bovine plasma in a representative experiment. Although considerable purification was obtained by DEAE Sephadex chromatography, this step was accompanied by a considerable loss of factor $\mathrm{X}$ because only the second part of the eluted bovine factor- $\mathrm{X}$ activity was used for further purification. The final yield of bovine factor $\mathrm{X}$ was in the order of $4 \%$, and an approximately 5,000 -fold purification was reached.

effluent, eluted at luted at

\section{Discussion}

Our aim was to find schemes by which factors II, VII, IX and X can be isolated from the same batch of bovine plasma as separate entities (fig. 12). Under our conditions, DEAE Sephadex chromatography resulted in separation of coagulation factor activity from many other plasma proteins, in- 


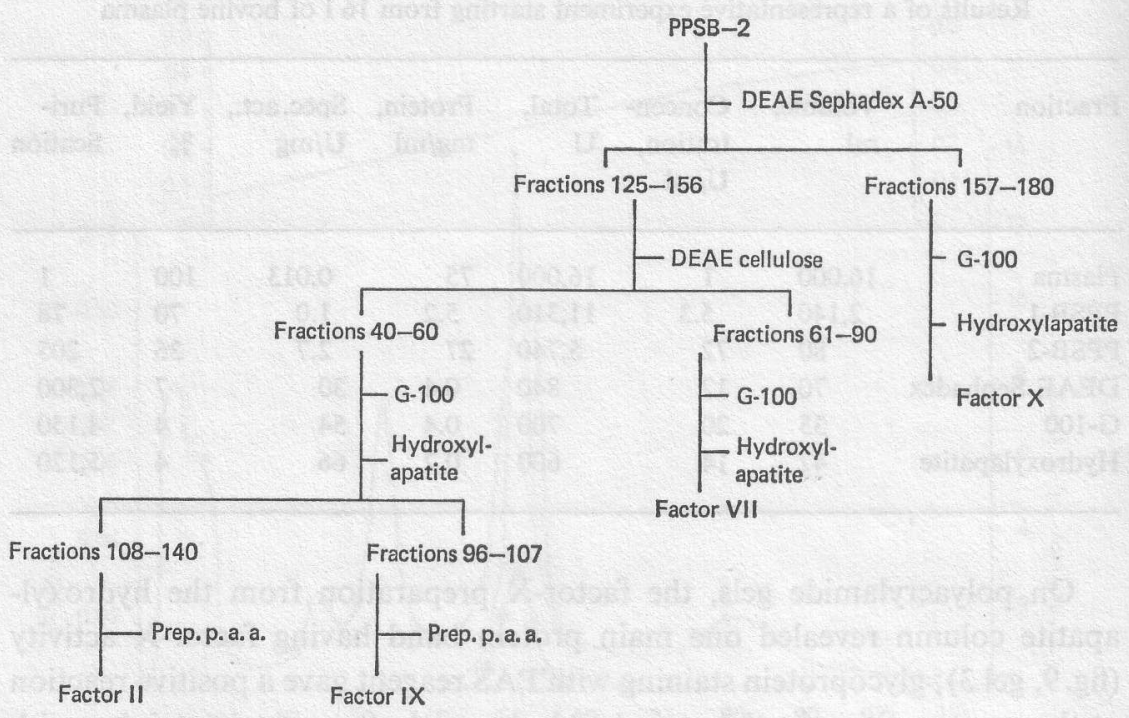

Fig. 12. Purification scheme for factors II, VII, IX and X.

cluding albumin, $\gamma$-globulin and fibrinogen. In accordance with other authors $[13,18,34,45]$, a partial separation was effected between the factors II and X, the latter having a much higher affinity for the anion exchanger.

The presence of DFP appeared to be necessary for prevention of activation of coagulation factors due to chromatographic procedures, as has been established by JACKSON and HANAHAN [17]. Even in the presence of DFP, factor $\mathrm{X}$ eluted in a double peak as was observed previously by JACKSON et al. [18] and by MILSTONE et al. [31]. We can confirm the finding of JACKSON and HANAHAN [17] that both kinds of factor X have the same mobility on polyacrylamide electrophoresis. We were able to demonstrate that the protein peak eluted at the lower ionic strenght contained factor $\mathrm{X}_{\mathrm{a}}$, the one at higher ionic strength only factor X [4]. Thus, DFP did not completely abolish this activated factor $\mathrm{X}$. In some experiments, the peak with factor $\mathrm{X}_{\mathrm{a}}$ activity gave rise to double-peak formation on G-150 gel filtration, the two species having molecular weights of 115,000 and 88,000 . Chromatography or electrophoresis in the presence of sodium dodecyl sulfate (SDS) did not give any indication of the occurrence of aggregation of factor $\mathrm{X}$ with 
other plasma material. By gel filtration, several authors determined a molecular weight for factor $X$ of about $85,000[13,18,34]$ which observation was also made for our factor-X preparation.

The best purification of factor $\mathrm{X}$ was achieved by taking the second part of the factor-X peak from DEAE Sephadex. The resulting factor- $X$ preparation showed one main band on analytical polyacrylamide electrophoresis, and one precipitation line on Ouchterlony plates against rabbit antitotal bovine serum-antiserum or rabbit antibovine factor- $\mathrm{X}$ antiserum and on immunoelectrophoresis [38].

The yield was poor, because a part of factor-X activity was left in the first DEAE Sephadex peak, which was used for the purification of factors II, VII, and IX. In the factor-X preparation, the relative amounts of factor X and factor VII have repeatedly been found in a ratio of 10:1. It is known that pure factor $\mathrm{X}$ also shortens the recalcification time of factor VII-deficient plasma containing $50 \%$ factor $\mathrm{X}$. We cannot conclude from clotting assays that factor VII was absent in the factor-X preparation, but the factorVII activity measured can be explained by the influence of factor $\mathrm{X}$ on the factor-VII assay.

The factor-VII preparation obtained after hydroxylapatite chromatography does not significantly shorten the recalcification time of factor X-deficient bovine plasma. So, we concluded factor $\mathrm{X}$ to be absent in the factorVII preparation. The molecular weight of bovine factor VII ranged from 72,000 to 62,000 , as judged from G-100 gel filtration; this was in agreement with the observations of other investigators [11]. The yield of factor VII was poor, mainly because chromatographic procedures gave rise to activation phenomena in the factor-VII molecules, making the factor more labile. When DFP was added to the eluting phosphate buffer after aluminum hydroxide adsorption of factor VII from bovine plasma, a lower factor-VII activity was found in the eluate than when DFP was omitted.

Factor II and factor IX could not be separated by DEAE cellulose chromatography $[9,35,45]$. Partial separation of these factors was achieved by hydroxylapatite chromatography [27], as has been shown also for the human coagulation factors [5, 43]. In our experiments, factor II eluted at a lower phosphate concentration than was found for human prothrombin.

On both analytical and preparative electrophoresis, factor IX showed a higher electrophoretic mobility than factor II; this result was not obtained by Cox and Hanahan [9].

Our results are in agreement with the observation of PECHET and SMITH [35], who showed factor IX to have a lower isoelectric point than factor II. 
The molecular weights of bovine factors II and IX were determined by G-100 gel filtration to be approximately 82,000 for both factors [9, 45]. Controversially, no indication of multiple factor-II elution patterns or factor-II polymorphism was obtained in the present study [2, 3, 22, 28].

The factor-II preparation still contained contaminating proteins. On immunoelectrophoresis of this preparation against antitotal bovine serumantiserum, two precipitation lines were observed, as was also the case with rabbit antibovine prothrombin antiserum, obtained by injecting this prothrombin preparation into rabbits [38]. On polyacrylamide electrophoresis of the factor-II preparation, one main protein band, coinciding with factor-II activity, was observed, together with a thin, slightly more anodal protein band.

Factor-IX preparations still contained about $5 \%$ factor-II activity. On polyacrylamide electrophoresis, one protein band coinciding with factor-IX activity was observed. Immunodiffusion experiments of the preparation against rabbit antibovine factor-IX antiserum showed only one precipitation line, as was also the case for immunoelectrophoresis experiments with the same antiserum [38].

\section{References}

1 ANDREWS, P.: Estimation of the molecular weights of proteins by Sephadex gel filtration. Bioch.J.91: 222-233 (1964).

2 ARonson, D.L.: Chromatographic differentiation of human prothrombin. Thromb. Diath. haemorrh. 16: 491-496 (1966).

3 ARONSON, D.L. and MÉNACHÉ, D.: Chromatographic analysis of the activation of human prothrombin with human thrombokinase. Biochemistry 5: 2635-2640 (1966).

4 Aronson, D.L. and Mustafa, A.J.: Two forms of the human prothrombin converting enzyme (active factor X). Proc. Soc. Exp. biol. Med.137: 1262-1266 (1971).

5 Aronson, D.L.; Mustafa, A.J., and Mushinsky, J. G.: Purification of human factor $\mathrm{X}$ and comparison of peptide maps of human factor $\mathrm{X}$ and prothrombin. Biochim. biophys. Acta 188: 25-30 (1969).

6 Biggs, R. and Macfarlane, R. G.: Human blood coagulation and its disorders, 3rd ed. (Blackwell, Oxford 1962).

7 BRuning, P.F. and Loeliger, E.A.: Prothrombal, a new concentrate of human prothrombin complex for clinical use. Brit. J. Haemat. 21: 377-398 (1971).

8 Casillas, G.; Simonetti, C., and Pavlovsky, A.: Chromatographic behaviour of clotting factors. Brit.J. Haemat. 16: 363-372 (1969).

9 Cox, A.C. and HANAHAN, D. J.: The isolation of undegraded bovine prothrombin and its partial characterization. Biochim. biophys. Acta 207: 49-64 (1970). 
ermined by

ors $[9,45]$.

patterns or $22,28]$.

oteins. On ine serumcase with g this prorophoresis h factor-II al protein

tivity. On factor-IX reparation cipitation with the

gel filtra-

Thromb.

ivation of 40 (1966). converting han factor Biochim. rders, 3rd f human

aviour of

mbin and
10 DAvIs, B. J.: Disc electrophoresis. II. Method and application to human serum proteins. Ann. N.Y.Acad. Sci. 121: 404-416 (1964).

11 Deutsch, E.; Lechner, K., and Schmer, G.: On the purification of factor VII from bovine plasma. Thromb. Diath. haemorrh. Suppl. 20: 275-277 (1966).

12 Deutsch, E. und Schaden, W.: Zur Reinigung und Charakterisierung des VII. Blutgerinnungsfaktors. Biochem.Z.324: 266-269 (1953).

13 Esnouf, M.P. and Williams, W.J.: The isolation and purification of a bovine plasma protein which is a substrate for the coagulant fraction of Russell's viper venom. Biochem.J.84: 62-71 (1962).

14 Gladhaug, A. and PrYdz, H.: Purification of the coagulation factors VII and X from human serum. Biochim. biophys. Acta 215: 105-111 (1970).

15 GoRDon, A.H. and Lours, L. N.: Preparative acrylamide electrophoresis: a single gel system. Analyt. Biochem. 21: 190-200 (1967).

16 Ingwall, J.S. and Scheraga, H. A.: Purification and properties of bovine prothrombin. Biochemistry 8: 1860-1869 (1968).

17 JACKSON, C. M. and HANAHAN, D. J.: Studies on bovine factor X, part II. Biochemistry 7: 4506-4517 (1968).

18 JACKSON, C.M.; Johnson, T.F., and HANAHAN, D. J.: Studies on bovine factor X, part I. Biochemistry 7: 4492-4505 (1968).

19 Josso, F. and Benarous, R.: Personal commun. (1971).

20 Keyzer, J.W.: Staining of serum glycoprotein after electrophoretic separation in acrylamide gels. Analyt. Biochem.9: 249-252 (1964).

21 KOLLER, F.; LOELIGER, E.A., and DUCKERT, F.: Experiments on a new clotting factor. Factor VII. Acta haemat., Basel 6: 1-10 (1951).

22 Lanchantin G.F.; FrIEDMAN J.A., and HaRT, D.W.: On the occurrence of polymorphic human prothrombin. J.biol. Chem. 243: 476-486 (1968).

23 LANGE J.A. DE and HEMKER, H.C.: Inhibition of blood coagulation factors by serine esterase inhibitors. FEBS Letters 24: 265-268 (1972).

24 LechNER, K. und Deutsch, E.: Eine einfache Methode zur Herstellung von menschlichem Faktor VII Mangelplasma. Thromb. Diath. haemorrh. 18: 252-258 (1968).

25 LI, L.F. and Olson, R.E.: Purification and properties of rat prothrombin. J.biol. Chem. 242: 5611-5616 (1967).

26 Lowry, O.H.; Roseborough, N.J.; FARR, A.F., and RANDALl, R.J.: Protein measurements with the Folin phenol reagent. J. biol. Chem. 193: 265-276 (1971).

27 Magnusson, S.: Fractionation of bovine prothrombin preparations by gradient chromatography on TEAE-cellulose columns. Ark. Kemi 24: 217-235 (1965).

28 MAGNUSSON, S.: Purification of prothrombin from human citrated plasma fraction II + III (Cohn's method 6). Ark. Kemi 24: 367-374 (1965).

29 MALHOtRA, O.P. and CARTER, J.R.: Modified method for the preparation of purified bovine prothrombin of high specific activity. Thromb. Diath. haemorrh. 19: 178-185 (1968).

30 MIISTONE, J.H.: Preparation of thrombokinase from bovine plasma. J. gen. Physiol.42: 665-676 (1959).

31 Milstone, J.H.; Oulianoff, N.; Saxton, R.T., and Milstone, V.K.: Partial and selective inactivation of thrombokinase by chymotrypsin. Yale J.Biol.Med.43: 223-235 (1971). 
32 MunRo, F.L. and MUNRO, M.P.: The preparation of prothrombin by adsorption on and elution from aluminum hydroxide. Arch. Biochem. Biophys. 15: 295-306 (1947).

33 OWREN, P.A. and AAS, K.: The control of dicumarol theory and the quantitative determination of prothrombin and proconvertin. Scand.J. clin. Lab. Invest. 3: 201-218 (1951).

34 Papahadjopoulos, D.; Yin, E.T., and Hanahan, D.J.: Purification and properties of bovine factor X: molecular changes during activation. Biochemistry 3: 1931-1939 (1964).

35 Pеснет, L. and Sмith, J.A.: The separation of clotting factors II (prothrombin) and IX (plasma thromboplastin component) by isoelectric focussing. Biochim. biophys. Acta 200: 475-485 (1970).

36 PEREIRA, M. and CourI, D.: Studies on the site of action of dicumarol on prothrombin synthesis. Biochim. biophys. Acta 237: 348-355 (1971).

37 Pratt, J.J. and Dangerfield, W. G.: Polyacrylamide gels of increasing concentration gradient for the electrophoresis of lipoproteins. Clin.chim. Acta 23: 189-201 (1969).

38 ReEKeRS, P.; Kop-KLAASSEN, B. H.M., and HeMKer, H. C.: In press.

39 SCHEIDEGGER, J.J.: Une micro-méthode de l'immuno-électrophorèse. Int. Arch. Allergy 7: 103-110 (1955).

40 Seegers, W.H. and Landaburu, R.H.: Purification of prothrombin and thrombin by chromatography on cellulose. Canad.J. Biochem. Physiol.38: 1405-1410 (1960).

41 Streuli, F.: Personal commun. (1966).

42 SUMNER, B.: A method for the colorimetric determination of phosphorus. Science 100: 413-414 (1944).

43 Swart, A.C.W. and Hemker, H. C.: Separation of blood coagulation factors II, VII, IX, and $\mathrm{X}$ by gel filtration in the presence of dextran blue. Biochim. biophys. Acta 222: 692-695 (1970).

44 Swart, A.C.W.; KlaAssen, B.H.M.; Bloys-Van Treslong-De Groot, C.H.F., and HEMKER, H.C.: The adsorption of blood coagulation factors II, VII, IX, and X from human plasma to aluminium hydroxide. Thromb. Diath. haemorrh. 27: 490-501 (1972).

45 Tishkoff, G.H.; Williams, L.V., and Brown, D.H.: Preparation of highly purified prothrombin complex. J.biol. Chem. 243: 4151-4167 (1968).

46 VeltKamp, J.J.; Drion, E.F., and Loeliger, E.A.: Detection of the carrier state in hereditary coagulation disorders. Thromb. Diath. haemorrh. 19: 279-293 (1968).

Request reprints from: Dr.P.ReEkers, Blood Transfusion Service, St. Radboud Ziekenhuis, Nijmegen (The Netherlands) 